\title{
Microvessel density and heparanase over- expression in clear cell renal cell cancer: correlations and prognostic significances
}

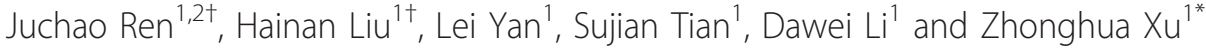

\begin{abstract}
Background: Tumor angiogenesis is important in the progression of malignancies, and heparanase plays an important role in sustaining the pathology of clear cell renal cell cancer (ccRCC). The study was carried out to investigate the correlations between microvessel density (MVD) and heparanase expression containing prognostic significances in the patients with ccRCC.

Methods: Specimens from 128 patients with cCRCC were investigated by immunohistochemistry for MVD. RT-PCR and immunohistochemistry were used to detect heparanase expression. Correlations between MVD, heparanase expression, and various clinico-pathological factors were studied. The prognostic significances of MVD and heparanase expression were also analysed.
\end{abstract}

Results: We discovered a statistically significant prevalence of higher MVD in CCRCC compared with adjacent normal renal tissues. MVD was positively correlated with TNM stage and distant metastasis in CCRCC patients, and was also correlated with the expression level of heparanase.

Heparanase is over-expressed and correlated with TNM stage, histologic grade, distant metastasis and lymphatic metastasis in ccRCC. High MVD and heparanase over-expression inversely correlate with the survival of ccRCC patients.

Conclusions: Heparanase contributes to angiogenesis of $c C R C C$ and over-expression of heparanase is an independent predictors of prognosis for ccRCC. MVD is correlated with tumor development and metastasis in CCRCC.

Keywords: clear cell renal cell carcinoma, microvessel density, heparanase, prognosis

\section{Background}

Renal cell carcinoma (RCC) is the most common malignant tumor of adult kidney [1]. Approximately $30 \%$ of the patients will develop to metastatic disease after curative surgery [2]. Clear cell renal cell carcinoma(ccRCC) is the most pathological types of RCC which has various clinical-pathological characteristics and prognostic factors. Angiogenesis is one of the major factors in the progression of malignancies, and tissue angiogenesis can be quantified by counting microvasculars in a certain

\footnotetext{
* Correspondence: xuzhonghuamd@yahoo.com.cn

+ Contributed equally

'Department of Urology, Qilu Hospital, Shandong University, 107\# Wenhua

Xi Road, Jinan, 250012 P.R. China Full list of author information is available at the end of the article
}

area by immunohistochemical staining (microvessel density, MVD) [3]. So far MVD has been considered as a potential prognostic marker in some tumors $[4,5]$.

Heparanase(HPA) is an endo- $\beta$-D-glucuronidase that has the activity of cleaving heparan sulfate (HS) side chains of heparan sulfate proteoglycans (HSPGs) [6]. HSPGs are not only the major proteoglycans of the extracellular matrix (ECM) and basement membrane (BM) which play a key role in preventing tumor cells invasion and metastasis, but also expressed on cell surfaces [7]. It is well known that heparanase activity is concerned with angiogenesis, inflammation, and cancer metastasis [8]. Heparanase over-expression inversely correlates with survival of patients with gastric [9], pancreatic [10], cervical [11], colorectal [12], bladder [13] and prostate [14] cancer.
C Biomed Central 
The description about the relationship between heparanase and MVD has not been so far done in previous studies. Our study examined MVD and heparanase expression in 128 patients with ccRCC and analyzed the correlations between the clinical-pathological parameters including MVD and heparanase expression. Moreover, we analyzed the prognostic significances of MVD and heparanase expression for ccRCC.

\section{Methods}

\section{Patients}

The tumour specimens and corresponding normal renal tissues were obtained from 128 patients with ccRCC between 2002 and 2008. All the ccRCCs were staged according to the 1997 TNM staging system [15]. Nuclear grade was on the basis of the Fuhrman criteria [16]. Clinical data of all the patients were collected from hospitalization and subsequent records. All the patients were informed of the study and consented to using their renal tissues for the investigation. Our study was also approved by the local ethics committee. All the patients were underwent radical nephrectomy, and none of them received chemotherapy or radiation therapy before surgery. The specimens were stored in liquid nitrogen for RT-PCR, and paraffin-embedded sections were prepared for immunohistochemistry analysis. We were keeping follow-up of 70 patients, 28 of them were alive at the end of the follow-up. Detailed information is listed in Table 1.

\section{Immunohistochemistry}

Five-micron paraffin sections were prepared for the experiment. Staining of the sections for heparanase was performed as previously described [17]. SP immunohistochemistry method and DBA staining were performed. Block nonspecific binding was performed with $5 \%$ bovine serum albumin(BSA) for 60 minutes at room temperature,

Table 1 MVD and Expression of HPA According To Clinical-pathological Parameters in ccRCC Tissues

\begin{tabular}{|c|c|c|c|c|c|c|c|}
\hline \multirow[t]{2}{*}{ Variables } & \multirow[t]{2}{*}{$n$} & \multirow[t]{2}{*}{$\%$} & \multicolumn{2}{|c|}{ HPA } & \multirow[t]{2}{*}{$P$} & \multirow[t]{2}{*}{ MVD } & \multirow[t]{2}{*}{$P$} \\
\hline & & & - & + & & & \\
\hline Total & 128 & 100 & 32 & 96 & & $101.64 \pm 23.00$ & \\
\hline \multicolumn{8}{|l|}{ Gender } \\
\hline Male & 82 & 64.1 & 21 & 61 & 0.832 & $101.39 \pm 24.54$ & 0.133 \\
\hline Female & 46 & 35.9 & 11 & 35 & & $102.07 \pm 20.04$ & \\
\hline \multicolumn{8}{|c|}{ Age, Years (Median 55) } \\
\hline$\leq 55$ & 61 & 47.7 & 15 & 46 & 0.919 & $102.02 \pm 20.49$ & 0.069 \\
\hline$>55$ & 67 & 52.3 & 17 & 50 & & $101.27 \pm 25.14$ & \\
\hline \multicolumn{8}{|l|}{ Tumor size } \\
\hline$\leq 5 \mathrm{~cm}$ & 83 & 64.8 & 20 & 63 & 0.748 & $101.93 \pm 24.53$ & 0.058 \\
\hline$>5 \mathrm{~cm}$ & 45 & 35.2 & 12 & 33 & & $101.11 \pm 19.92$ & \\
\hline \multicolumn{8}{|l|}{ Tumor stage } \\
\hline $\mathrm{T}_{1}$ & 50 & 39.1 & 20 & 30 & & & \\
\hline $\mathrm{T}_{2}$ & 41 & 32 & 8 & 33 & & & \\
\hline$T_{3}$ & 27 & 21.1 & 3 & 24 & & & \\
\hline $\mathrm{T}_{4}$ & 10 & 7.8 & 1 & 9 & & & \\
\hline \multicolumn{8}{|c|}{ Lymphatic metastasis } \\
\hline $\mathrm{N}_{0}$ & 108 & 84.4 & 31 & 77 & 0.025 & $101.81 \pm 23.84$ & 0.056 \\
\hline$N_{1-3}$ & 20 & 15.6 & 1 & 19 & & $100.72 \pm 17.91$ & \\
\hline \multicolumn{8}{|c|}{ Distant metastasis } \\
\hline$M_{0}$ & 114 & 89.1 & 32 & 82 & 0.022 & $99.96 \pm 23.66$ & $<0.0001$ \\
\hline$M_{1}$ & 14 & 10.9 & 0 & 14 & & $113.14 \pm 12.88$ & \\
\hline \multicolumn{8}{|l|}{ TNM stage } \\
\hline$|-| \mid$ & 76 & 59.4 & 27 & 49 & 0.001 & $95.96 \pm 21.39$ & $<0.0001$ \\
\hline III-IV & 52 & 40.6 & 5 & 47 & & $108.94 \pm 22.94$ & \\
\hline \multicolumn{8}{|c|}{ Histologic grade } \\
\hline $\mathrm{G}_{1}-\mathrm{G}_{2}$ & 94 & 73.4 & 27 & 67 & 0.106 & $101.49 \pm 24.02$ & 0.238 \\
\hline $\mathrm{G}_{3}-\mathrm{G}_{4}$ & 34 & 26.6 & 5 & 29 & & $102.04 \pm 20.00$ & \\
\hline \multicolumn{8}{|c|}{ Venous invasion } \\
\hline Negative & 106 & 82.8 & 26 & 80 & 0.787 & $101.79 \pm 23.99$ & 0.109 \\
\hline Positive & 22 & 17.2 & 6 & 16 & & $100.91 \pm 17.61$ & \\
\hline
\end{tabular}

-: negative expression + : positive expression 
without washing, and the slides were incubated with antiheparanase antibody (sc-25825, 1:100 dilution) and antiCD34 antibody (sc-19621, 1:100 dilution) at $4^{\circ} \mathrm{C}$ overnight. As a negative control, the primary antibody was replaced with phosphatebuffered saline (PBS). After washing with PBS, the slides were incubated with horseradish peroxidase-conjugated goat anti-rabbit IgG according to the manufacturer's instructions at $37^{\circ} \mathrm{C}$ for $45 \mathrm{~min}$. Color was developed with DAB Horseradish Peroxidase Color Development Kit (P0202, Beyotime). The slides were evaluated by two independent pathologists who were blind to the status of the patients according to the intensity of cancer cells that were stained (-: negative, + : weak, ++ : strong) as described [18].

\section{Quantification of Microvasculature Density}

The primary antibody against CD34 was used to evaluate microvessel density (MVD), which was performed according to the methods previously described [19]. Endothelial cell clusters and endothelial cells which were stained brownish-yellow could be considered as a single microvessel. Undefined endothelial cell fragments and the visible vascular lumen were not counted as microvessels. Branching structures were considered as single vessel if there was not a break in continuity of the structure. Initially, the entire section was scanned for high-MVD areas by low microscopic magnification (40x and 100x) to identify the hot spots (representing the highest vascular density), and then brown-stained endothelial clusters were counted under light microscope observation $200 \times$ magnification. Results were shown as mean microvessel counts of the three hot spots under 200× magnification [20]. High MVD group and low MVD group were classified by the the median MVD counts of ccRCC patients. Figure 1A-1 showed a representative field of high MVD in ccRCC. For comparison, Figure 1A-2 depicted a representative field of ccRCC with low MVD.

RNA isolation and semi-quantitative reverse transcriptase polymerase chain reaction (RT-PCR)

Total RNA was extracted from RCC tissues and adjacent normal renal tissues using TRIzol (Invitrogen) according to the manufacturer's instructions, and then quantified by spectrophotometry. The polymerase chain reaction (PCR) primers designed by Premier Primer 5.0 software were as following: heparanase-5'-TTCGATCCCAAGAAGGAATCAAC-3' (forward) and 5'-GTAGTGATGCCATGTAAC TGAATC-3'(reverse), and $\beta$-actin-5'- GTGGGG CGC CCCAGGCACCA-3'(forward) and 5'-CTCCTTAATGTCACGCACGATTTC-3'(reverse). PCR products were separated by electrophoresis through a $1.5 \%$ agarose gel, stained by ethidium bromide, and visualized in ultraviolet light. The intensity of the bands was quantified with Scion Image software (Scion, Frederick, MD).

\section{Statistical Analysis}

MVD differentials were compared using t-test and univariate analysis of variance. Associations between heparanase expression and clinical-pathological parameters were analyzed using Chi Square test. Univariate association of survival was evaluated using Kaplan Meier curves, and tested by Log-Rank test. Multivariate analyses were performed according to Cox proportional hazards regression mode. (SPSS version 16.0 for Mac; SPSS, Inc., Chicago, IL, USA). $\mathrm{P}<0.05$ was considered to be statistically significant.

\section{Results}

The correlation of MVD in CcRCC with the clinicalpathological parameters

The mean MVD counts were 101.64 \pm 23.00 in ccRCC tissues, $32.52 \pm 7.85$ in corresponding normal renal tissues, with significant difference $(P<0.0001)$; The relationship between MVD counts and various clinical and histopathologic parameters was analyzed. The mean MVD counts were $108.94 \pm 22.94$ in advanced stage group (stage III-IV), $95.96 \pm 21.39$ in early stage group (stage I-II), with significant difference $(P<0.0001)$; $113.14 \pm 12.88$ in $\mathrm{M}_{1}$ group (with distant metastasis), $99.96 \pm 23.66$ in $\mathrm{M}_{0}$ group (without distant metastasis), with significant difference $(P<$ $0.0001)$; No significant association was demonstrated between MVD counts and patients' age ( $\leq 55$ years:102.02 \pm 20.49, $>55$ years: $101.27 \pm 25.14, P=0.069)$, gender $(\mathrm{m}$ : $101.39 \pm 24.54$, f: $102.07 \pm 20.04, P=0.113$ ), tumour sizes ( $\leq 5 \mathrm{~cm}: 101.93 \pm 24.53,>5 \mathrm{~cm}: 101.11 \pm 19.92, P=0.058$ ), histologic grade $\left(\mathrm{G}_{1}-\mathrm{G}_{2}: 101.49 \pm 24.02, \mathrm{G}_{3}-\mathrm{G}_{4}: 102.04 \pm\right.$ $20.00, P=0.238)$, lymphatic metastasis $\left(\mathrm{N}_{0}: 101.81 \pm 23.84\right.$, $\left.\mathrm{N}_{1-2}: 100.72 \pm 17.91, P=0.056\right)$ and venous invasion $\left(\mathrm{V}_{0}\right.$ : $\left.101.79 \pm 23.99, \mathrm{~V}_{1}: 100.91 \pm 17.61, P=0.109\right)$ (Table 1$)$.

\section{Heparanase is over-expressed and correlated with} progression and invasion in ccRCC

Expression of heparanase was observed in 96 tumour samples (75\%) (Figure 1B and 1C), conversely in 25 adjacent normal tissues $(19.5 \%)(P<0.0001)$. Heparanase expression was correlated with TNM staging $(P=0.001)$, distant metastasis $(P=0.022)$ and lymphatic metastasis $(P=0.025)$ (Table 1$)$.

\section{Correlations between MVD and heparanase expression}

The mean MVD counts in the group of heparanase-negative expression, weak heparanase expression and strong heparanase expression were $97.37 \pm 21.13,101.86 \pm 22.53$ and $103.97 \pm 24.10(P<0.0001)$, respectively.

MVD, heparanase expression and postoperative survival of the patients

The overall survival (OS) rate of patients with highMVD was significantly lower than that with low-MVD 


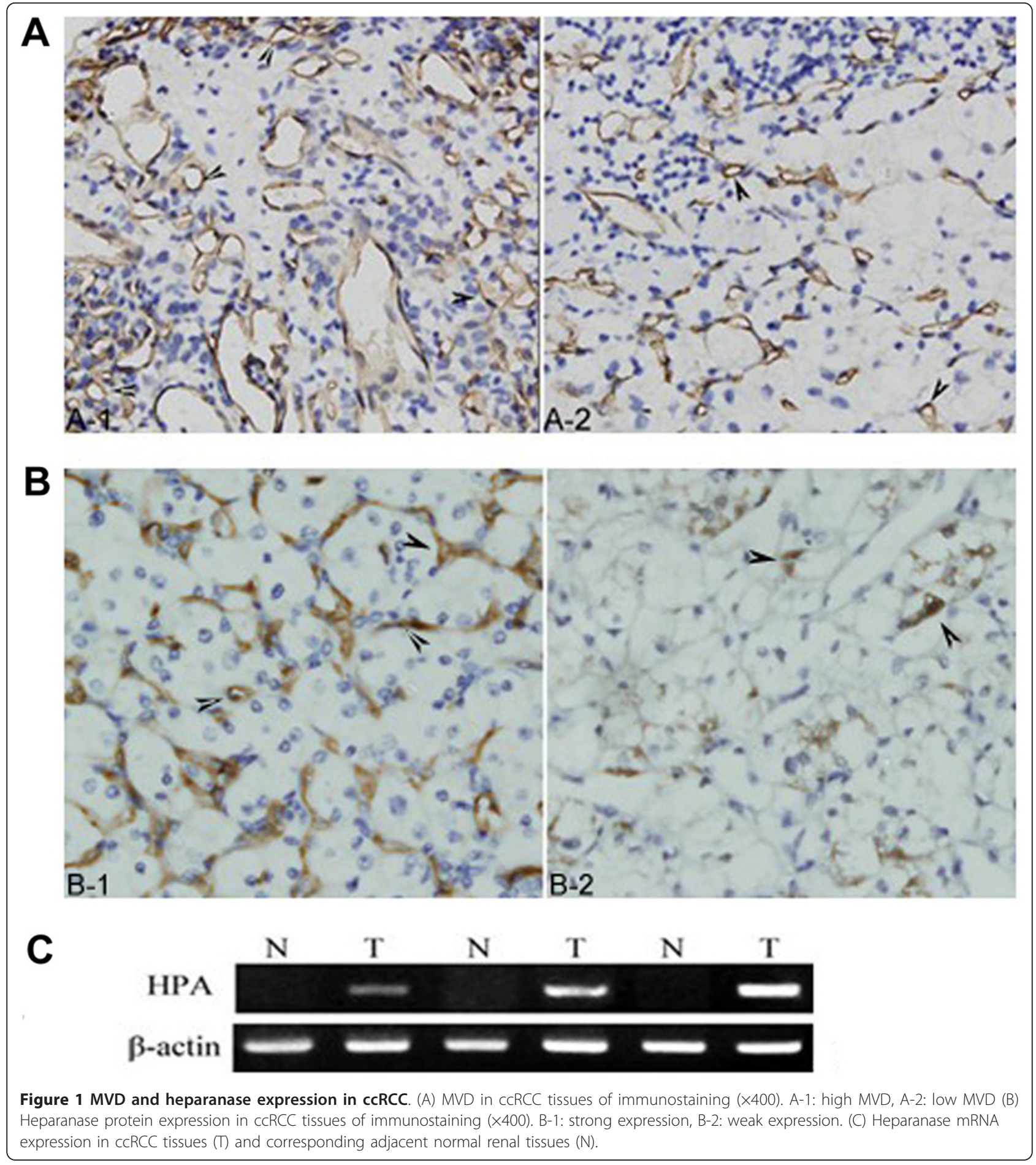

(Log-Rank Test, $P=0.022$, Figure $2 \mathrm{~A}$ ). The OS rate of patients with heparanase- positive was significantly lower than that with heparanase-negative (Log-Rank Test, $P<0.0001$, Figure $2 B$ ). In addition, the multivariate analysis indicated that heparanase-positive expression $(P=0.006)$ and distant metastasis $(P<0.0001)$ were independent prognostic factors for ccRCC patients (Table 2).

Rates and P values in disease-specific survival according to the status of MVD and heparanase expression were actually equal to those in overall survival of the patients. 

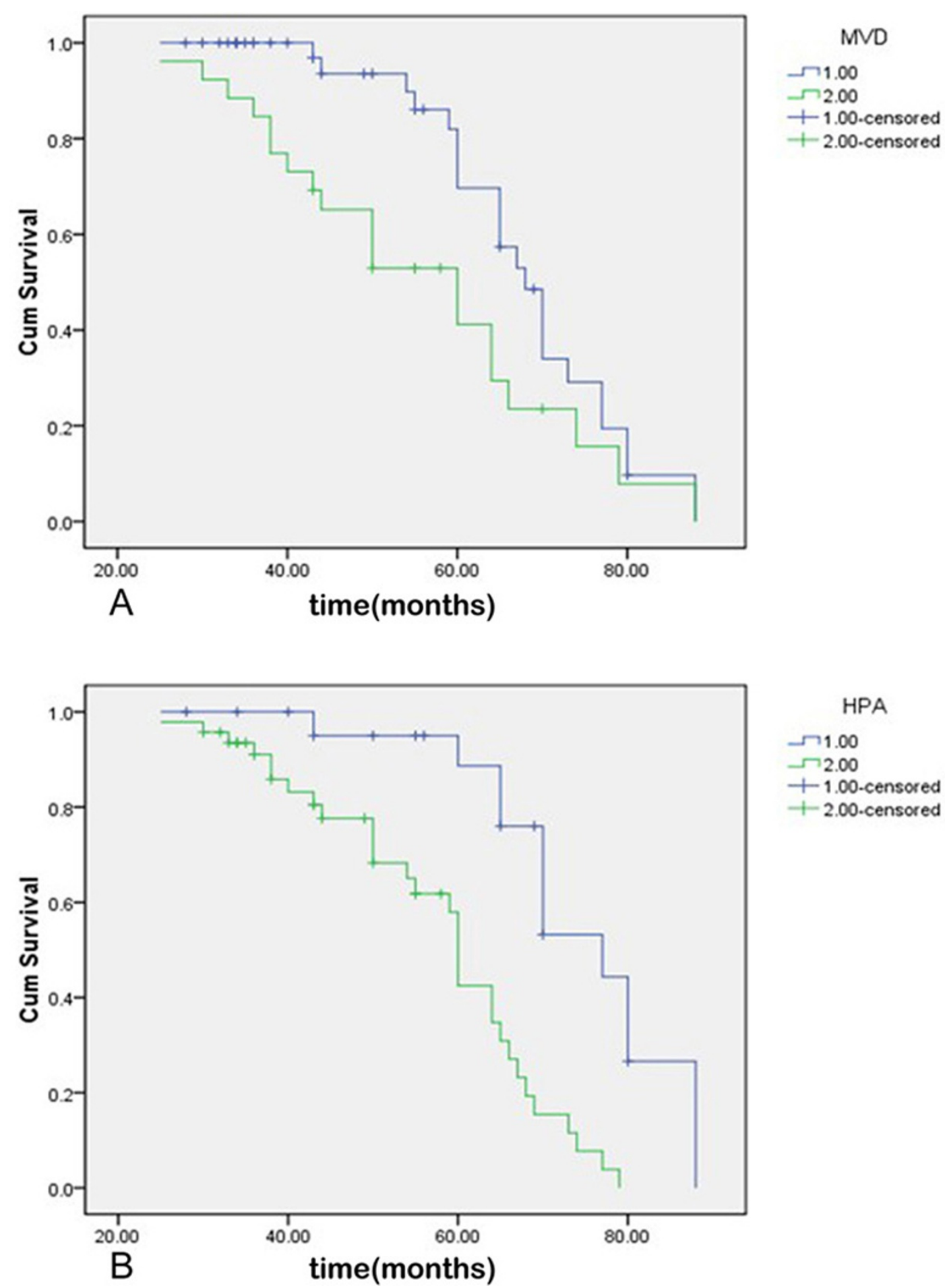

HPA

$\neg 1.00$

$-2.00$

+1.00 -censored

$+2.00 \cdot$ censored

Figure 2 Survival Curves of the Patients with ccRCC. (A) on the basis of MVD counts in tumor tissues, 1: low MVD group, 2: high MVD group (B) on the basis of HPA expression in tumor tissues, 1: negative expression group, 2: positive expression group.

\section{Discussion}

As shown in previous studies, heparanase plays an important role in sustaining the pathology of various malignancies [14,17,21-24]. Invasion and metastasis of tumor cells depend on the ability of the cells invading tissue barriers which are composed of BM and ECM. HS and HSPGs, as crucial structural components, are contained in BM and ECM, and are substrates of 
Table 2 Cox regression analysis in overall survival of RCC patients

\begin{tabular}{|c|c|c|c|}
\hline Risk factors & RR & $95 \% \mathrm{Cl}$ & $P$ \\
\hline \multicolumn{4}{|c|}{ Primary tumor stage } \\
\hline $\mathrm{T}_{1,2}$ & 1.579 & $0.763-3.266$ & 0.218 \\
\hline \multicolumn{4}{|c|}{$T_{3,4}$} \\
\hline \multicolumn{4}{|c|}{ Distant metastasis } \\
\hline$M_{0}$ & 5.859 & $2.186-15.706$ & $<0.0001$ \\
\hline \multicolumn{4}{|l|}{$M_{1}$} \\
\hline \multicolumn{4}{|l|}{ HPA staining } \\
\hline Negative & 3.584 & $1.448-8.870$ & 0.006 \\
\hline \multicolumn{4}{|l|}{ Positive } \\
\hline \multicolumn{4}{|l|}{ MVD } \\
\hline Low & 0.930 & $0.453-1.911$ & 0.844 \\
\hline High & & & \\
\hline
\end{tabular}

RR: relative risk; $95 \% \mathrm{Cl}$ : 95\% confidence interval

heparanase that is capable of cleaving HS side chains [25]. Consequently, tumor cells are facilitated penetrating the BM and ECM barriers. This enzymatic activity of heparanase contributes to the development of ccRCC. Thus, heparanase may play biological roles in multiple ways other than its enzymatic activity, such as mediation of cell adhesion [26], activation of CD44 variant exon-3 [27], promoting VEGF expression via Src pathway [28], enhancing Akt signaling pathway and stimulating PI3Kand p38-dependent endothelial cell migration and invasion [29], modulation of endothelial cell permeability and integrity via syndecan family members $[30,31]$, promotion of basic fibroblast growth factor releasing and inhibition of activated $\mathrm{T}$ lymphocytes [32], and so on.

Degradation of the subendothelial BM, migration and proliferation of the endothelial cells to form vascular sprouts are crucial early events during angiogenesis [33]. The activities of heparanase and some growth factors binding HS, such as aFGF (acid fibroblast growth factor), bFGF (basic fibroblast growth factor), VEGF (vascular endothelial growth factor) are directly involved in above progresses [28]. Furthermore, cell surface HS can interact with HS binding growth factors and facilitate the signal transduction [34]. Heparanase promotes migration and proliferation of the endothelial cells by above mechanism [25]. Accordingly, we evaluated the angiogenesis of ccRCC by detecting commonly used pan-endothelial marker (CD34) as previous studies [5,35].

Our study found the prevalence of elevated angiogenesis and heparanase over-expression in ccRCC, at the same time, we firstly described the close correlations between angiogenesis and heparanase expression in ccRCC. Tumor angiogenesis was closely related to the development and metastasis of ccRCC, and heparanase over-expression was associated with invasion and prognosis that was consistent with previous description [36]. Above results indicated that antiangiogenesis by inhibiting heparanase maybe more effective treatment for ccRCC.

The study showed poor survival of patients with high MVD and heparanase over-expression. Tumor size, tumor stage, nuclear grade, and metastasis status have been reported to be of prognostic significance for RCC $[37,38]$. Our study showed that high MVD had prognostic significance for ccRCC, which was not consistent with previous description [39].

In view of the above, heparanase may serve as a therapeutic target for ccRCC. In fact, PI-88, a representative heparanase inhibitor, has already been tested in clinical trial [40-42]. The application of heparanase inhibitors may be a promising therapeutic tool for ccRCC in particular.

Taken together, our findings demonstrate the tumor angiogenesis and the role of heparanase in ccRCC on the basis of clinical and pathological parameters, thus contributing to the basic understanding of the most common malignant tumour of adult kidney. In addition, the role of heparanase in tumor angiogenesis, the prognostic significance of heparanase over-expression for ccRCC are described.

\section{Conclusions}

Elevated angiogenesis is observed in ccRCC but almost absent in normal renal tissues. Elevated angiogenesis contributes to development and invasion of ccRCC. Heparanase over-expression is prevalent in ccRCC, which promotes tumor angiogenesis and indicates worse prognosis. Moreover, heparanase over-expression is an independent predictor of prognosis for ccRCC. Therefore, heparanase may serve as a potential therapeutic target for ccRCC.

\section{Abbreviations List}

MVD: microvessel density; HPA: heparanase; RCC: renal cell carcinoma; ccRCC: clear cell renal cell carcinoma; ECM: extracellular matrix; BM: basement membrane; HS: heparan sulfate; HSPGs: heparan sulfate proteoglycans; BSA: bovine serum albumin; OS: Overall survival.

\section{Acknowledgements}

The work was supported by the Natural Science Foundation of Shandong (No. ZR2010HM103) and Science and Technology Development Planning Foundation of Shandong (No.Y2003C10).

\section{Author details}

${ }^{1}$ Department of Urology, Qilu Hospital, Shandong University, 107\# Wenhua Xi Road, Jinan, 250012 P.R. China. ${ }^{2}$ Key Laboratory of Cardiovascular Remodeling and Function Research, Chinese Ministry of Education and Chinese Ministry of Public Health, 107\# Wenhua Xi Road, Jinan, 250012 P.R. China.

\section{Authors' contributions}

$J C R$ and HNL carried out experimental procedures and drafted manuscript.. LY, SJT and DWL participated in the study design and were involved in the 
collection of clinical data and specimens. ZHX guaranteed the whole study All authors read and approved the final manuscript.

\section{Authors' information}

${ }^{1}$ Department of Urology, Qilu Hospital, Shandong University, Jinan, P.R. China ${ }^{2}$ Key Laboratory of Cardiovascular Remodeling and Function Research, Chinese Ministry of Education and Chinese Ministry of Public Health, Jinan, P. R. China

\section{Competing interests}

The authors declare that they have no competing interests.

Received: 20 August 2011 Accepted: 2 December 2011

Published: 2 December 2011

\section{References}

1. Eble JN, Sauter G, Epstein JI, Sesterhenn IA: Pathology and Genetics of Tumours of the Urinary System and Male Genital Organs Lyon: IARCPress; 2004

2. Cohen HT, McGovern FJ: Renal-cell carcinoma. N Engl J Med 2005, 353:2477-2490.

3. Czekierdowski A, Czekierdowska S, Czuba B, Cnota W, Sodowski K Kotarski J, Zwirska- Korczala K: Microvessel density assessment in benign and malignant endometrial changes. J Physiol Pharmacol 2008, 59(Suppl 4):45-51.

4. Thelen A, Scholz A, Benckert C, Schroder M, Weichert W, Wiedenmann B, Neuhaus $P$, Jonas S: Microvessel density correlates with lymph node metastases and prognosis in hilar cholangiocarcinoma. J Gastroenterol 2008, 43:959-966.

5. Svagzdys S, Lesauskaite V, Pavalkis D, Nedzelskiene I, Pranys D, Tamelis A: Microvessel density as new prognostic marker after radiotherapy in rectal cancer. BMC Cancer 2009, 9:95

6. Vlodavsky I, Friedmann Y: Molecular properties and involvement of heparanase in cancer metastasis and angiogenesis. J Clin Invest 2001, 108:341-347

7. Yurchenco PD, Schittny JC: Molecular architecture of basement membranes. FASEB J 1990, 4:1577-1590.

8. Ferro V, Hammond E, Fairweather JK: The development of inhibitors of heparanase, a key enzyme involved in tumour metastasis, angiogenesis and inflammation. Mini Rev Med Chem 2004, 4:693-702.

9. Tang W, Nakamura $Y$, Tsujimoto M, Sato M, Wang X, Kurozumi K, Nakahara M, Nakao K, Nakamura M, Mori I, Kakudo K: Heparanase: a key enzyme in invasion and metastasis of gastric carcinoma. Mod Pathol 2002, 15:593-598.

10. Koliopanos A, Friess H, Kleeff J, Shi X, Liao Q, Pecker I, Vlodavsky I, Zimmermann A, Buchler MW: Heparanase expression in primary and metastatic pancreatic cancer. Cancer Res 2001, 61:4655-4659.

11. Shinyo $Y$, Kodama J, Hongo A, Yoshinouchi M, Hiramatsu $Y$ : Heparanase expression is an independent prognostic factor in patients with invasive cervical cancer. Ann Oncol 2003, 14:1505-1510.

12. Friedmann $Y$, Vlodavsky I, Aingorn $H$, Aviv A, Peretz T, Pecker I, Pappo O: Expression of heparanase in normal, dysplastic, and neoplastic human colonic mucosa and stroma. Evidence for its role in colonic tumorigenesis. Am J Pathol 2000, 157:1167-1175.

13. Gohji K, Hirano H, Okamoto M, Kitazawa S, Toyoshima M, Dong J, Katsuoka Y, Nakajima M: Expression of three extracellular matrix degradative enzymes in bladder cancer. Int J Cancer 2001, 95:295-301.

14. Lerner I, Baraz L, Pikarsky E, Meirovitz A, Edovitsky E, Peretz T, Vlodavsky I, Elkin M: Function of heparanase in prostate tumorigenesis: potential for therapy. Clin Cancer Res 2008, 14:668-676.

15. Hermanek $P$, Seib H, Wittekind C: Clinical significance and current status. Pathologe 1997, 18:153-159.

16. Fuhrman SA, Lasky LC, Limas C: Prognostic significance of morphologic parameters in renal cell carcinoma. Am J Surg Pathol 1982, 6:655-663.

17. Zetser A, Levy-Adam F, Kaplan V, Gingis-Velitski S, Bashenko Y, Schubert S, Flugelman MY, Vlodavsky I, Ilan N: Processing and activation of latent heparanase occurs in lysosomes. J Cell Sci 2004, 117:2249-2258.

18. Doweck I, Kaplan-Cohen V, Naroditsky I, Sabo E, llan N, Vlodavsky I: Heparanase localization and expression by head and neck cancer: correlation with tumor progression and patient survival. Neoplasia 2006 8:1055-1061.
19. Zubac DP, Bostad L, Kihl B, Seidal T, Wentzel-Larsen T, Haukaas SA: The expression of thrombospondin-1 and p53 in clear cell renal cell carcinoma: its relationship to angiogenesis, cell proliferation and cancer specific survival. J Urol 2009, 182:2144-2149.

20. Bai RJ, Cheng XG, Qu H, Shen BZ, Han MJ, Wu ZH: Solitary pulmonary nodules: comparison of multi-slice computed tomography perfusion study with vascular endothelial growth factor and microvessel density. Chin Med J (Engl) 2009, 122:541-547.

21. Ben-Izhak O, Kaplan-Cohen V, Ilan N, Gan S, Vlodavsky I, Nagler R: Heparanase expression in malignant salivary gland tumors inversely correlates with long-term survival. Neoplasia 2006, 8:879-884.

22. Vlodavsky I, Ilan N, Naggi A, Casu B: Heparanase: structure, biological functions, and inhibition by heparin-derived mimetics of heparan sulfate. Curr Pharm Des 2007, 13:2057-2073.

23. Cohen-Kaplan V, Doweck I, Naroditsky I, Vlodavsky I, Ilan N: Heparanase augments epidermal growth factor receptor phosphorylation: correlation with head and neck tumor progression. Cancer Res 2008, 68:10077-10085.

24. Nasser NJ: Heparanase involvement in physiology and disease. Cell Mol Life Sci 2008, 65:1706-1715.

25. Ilan N, Elkin M, Vlodavsky I: Regulation, function and clinical significance of heparanase in cancer metastasis and angiogenesis. Int J Biochem Cell Biol 2006, 38:2018-2039.

26. Goldshmidt O, Zcharia E, Cohen M, Aingorn H, Cohen I, Nadav L, Katz BZ, Geiger B, Vlodavsky I: Heparanase mediates cell adhesion independent of its enzymatic activity. FASEB J 2003, 17:1015-1025.

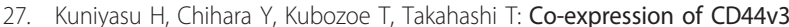
and heparanase is correlated with metastasis of human colon cancer. Int J Mol Med 2002, 10:333-337.

28. Zetser A, Bashenko Y, Edovitsky E, Levy-Adam F, Vlodavsky I, Ilan N: Heparanase induces vascular endothelial growth factor expression: correlation with p38 phosphorylation levels and Src activation. Cancer Res 2006, 66:1455-1463

29. Gingis-Velitski S, Zetser A, Kaplan V, Ben-Zaken O, Cohen E, Levy-Adam F, Bashenko Y, Flugelman MY, Vlodavsky I, llan N: Heparanase uptake is mediated by cell membrane heparan sulfate proteoglycans. J Biol Chem 2004, 279:44084-44092

30. Gavard J, Patel V, Gutkind JS: Angiopoietin-1 prevents VEGF-induced endothelial permeability by sequestering Src through mDia. Dev Cell 2008, 14:25-36

31. Yang Y, Macleod V, Miao HQ, Theus A, Zhan F, Shaughnessy JD Jr, Sawyer J, Li JP, Zcharia E, Vlodavsky I, Sanderson RD: Heparanase enhances syndecan-1 shedding: a novel mechanism for stimulation of tumor growth and metastasis. J Biol Chem 2007, 282:13326-13333.

32. Vaday GG, Lider O: Extracellular matrix moieties, cytokines, and enzymes: dynamic effects on immune cell behavior and inflammation. J Leukoc Biol 2000, 67:149-159.

33. Stetler-Stevenson WG: Matrix metalloproteinases in angiogenesis: a moving target for therapeutic intervention. J Clin Invest 1999, 103:1237-1241.

34. Vlodavsky I, Miao HQ, Medalion B, Danagher P, Ron D: Involvement of heparan sulfate and related molecules in sequestration and growth promoting activity of fibroblast growth factor. Cancer Metastasis Rev 1996, 15:177-186.

35. Jiang LJ, Shao CK, He D, Li WG, Wu XZ, Cai DZ: Correlations of extrocellular matrix metalloproteinase inducer and microvessel density to invasiveness of ameloblastoma. Chinese J Cancer 2008, 27:1263-1266

36. Mikami S, Oya M, Shimoda M, Mizuno R, Ishida M, Kosaka T, Mukai M, Nakajima M, Okada Y: Expression of heparanase in renal cell carcinomas: implications for tumor invasion and prognosis. Clin Cancer Res 2008, 14:6055-6061.

37. Pantuck AJ, Zeng G, Belldegrun AS, Figlin RA: Pathobiology, prognosis, and targeted therapy for renal cell carcinoma: exploiting the hypoxiainduced pathway. Clin Cancer Res 2003, 9:4641-4652.

38. Elmore JM, Kadesky KT, Koeneman KS, Sagalowsky Al: Reassessment of the 1997 TNM classification system for renal cell carcinoma. Cancer 2003, 98:2329-2334.

39. Sandlund J, Hedberg Y, Bergh A, Grankvist K, Ljungberg B, Rasmuson T: Evaluation of CD31 (PECAM-1) expression using tissue microarray in patients with renal cell carcinoma. Tumour Biol 2007, 28:158-164. 
40. Fairweather JK, Hammond E, Johnstone KD, Ferro V: Synthesis and heparanase inhibitory activity of sulfated mannooligosaccharides related to the antiangiogenic agent PI-88. Bioorg Med Chem 2008, 16:699-709.

41. Lewis KD, Robinson WA, Millward MJ, Powell A, Price TJ, Thomson DB,

Walpole ET, Haydon AM, Creese BR, Roberts KL, Zalcberg JR, Gonzalez R: A phase II study of the heparanase inhibitor PI-88 in patients with advanced melanoma. Invest New Drugs 2008, 26:89-94.

42. Basche M, Gustafson DL, Holden SN, O'Bryant CL, Gore L, Witta S, Schultz MK, Morrow M, Levin A, Creese BR, Kangas M, Roberts K, Nguyen T, Davis K, Addison RS, Moore JC, Eckhardt SG: A phase I biological and pharmacologic study of the heparanase inhibitor PI-88 in patients with advanced solid tumors. Clin Cancer Res 2006, 12:5471-5480.

doi:10.1186/1477-7819-9-158

Cite this article as: Ren et al:: Microvessel density and heparanase overexpression in clear cell renal cell cancer: correlations and prognostic significances. World Journal of Surgical Oncology 2011 9:158.

\section{Submit your next manuscript to BioMed Central} and take full advantage of:

- Convenient online submission

- Thorough peer review

- No space constraints or color figure charges

- Immediate publication on acceptance

- Inclusion in PubMed, CAS, Scopus and Google Scholar

- Research which is freely available for redistribution

Submit your manuscript at www.biomedcentral.com/submit 